\title{
Internal world representation in adolescents in the context of normal and abnormal development
}

\section{Joanna Kossewska}

\begin{abstract}
The article tries to briefly look at the process of identity development and content of internal world cognitive representation in the youth with normal and abnormal development. As it is reviewed the specific developmental conditions influence the subjective world representation as well as psychological outcomes of its differentiation related to normal and abnormal development.
\end{abstract}

Key words: world representation, identity development, hearing impairment, chronic illness.

\section{World representation and its regulative function}

Though the effectiveness of corrective interaction is conditioned on numerous factors, the inner representation of the world that the youth contributes to the contact with carers and therapists may be one of them. Man is not a passive recipient of the incoming information, but processes, selects and interprets it on the basis of the experiences en- 
coded in memory, which, as a result, leads to the creation of a subjective representation of reality in mind, what is an important element of identity and proper self-evaluation.

This representation, being a global cognitive representation, performs a crucial regulative function in conduct. This representation, so a system of judgments about the essence of the world (a real picture of the world consisting of ontological statements) tends to be distinguished from the outlook (being an ideal picture of the world), in which recognized values, that is the criteria of the world cognition and its evaluation, take an important place (Gurycka, 1994).

Subjective perception of oneself and the surrounding world, so building the picture of reality or its cognitive representation is the thing that determines the individual's subjectivity and individuality (Markus, 1983). Not the objectively existing world and its particular elements alone exert a crucial influence upon human behavior, but the subjective picture of the world, individually processed, constructed. Thus, reality representation in human mind has a double form. On one hand, it is of an individual character because it consists of representations of various episodes and events experienced by the individual, on the other hand, it takes the form of cognitive schemes including general representations, hypotheses on the surrounding reality (the world and oneself) as well as generalized knowledge, aside from a particular context. Schemes, fulfilling the role of patterns arrange experience, encode knowledge, so that it may be the basis of judgments, decisions, conclusions, predictions and expectations' formulation (Markus, 1983). Individual versions of reality created by the individual, function in the form of personal constructs being a generalized interpretation of facts, serving to characterizing the objects of our cognition (persons and situations) and eliciting similarities and differences among them. Personal constructs allow to construct experiences and give meaning to events, and through that they determine the perception of reality and anticipation of future events (Kelly, 1955 in Kofta, Doliński, 2000).

In the recent years, many interesting studies and discoveries have been carried out regarding the development of single objects and concepts cognitive representations (e. g. Bartmiński, 1990; Kielar-Turska, 1998, 2005), studies on the representation of the world as a whole are much rarer (Gurycka, 1994, Bulla, 1997, Świda-Zięba, 2000) and that seems to be particularly interesting as "the global representation of the world in human mind and his place in the world" (Gurycka 1994, p. 7), playing an important regulative function, implies the way of human conduct and conditions possibilities of coping with burdens, as well as the way of problem solving, and is a basic point of reference for his understanding of the world (Gurycka, Tarnowki, 1996).

The representation of the world happening "here and now" has a complex structure and consists of diverse elements marked out by the activity of the individual, which may be analyzed from the interpsychical perspective of Bioecological Model of Human Development (Santrock, 2007). The most important element connected with the functioning of the individual is the "Self" category which may be enriched with descriptive and 
evaluative elements, as well as those containing the developmental aspect. The "Self" category along with interpersonal relations with the closest family members (treated separately or jointly) create a microsystem. Other people, who are an important element of a mesosystem in which the individual lives, and the social environment presented as public institutions and establishments that create the level of exosystem (school, the scouts, place of work) also belong to the crucial categories appearing in the subjective world. Both adults and the youth in their subjective worlds allow for the presence of such elements of the macrosystem as: the economic and political environment (the state, political system, nationality) and natural environment (the nature, nature protection, civilization diseases). Chronosystem - refers to the pattern of environmental events and transitions over time. It includes the individual time perspective.

Three levels of description are taken into consideration when characterizing the mental representation of the world. The first level reveals the material aspect (declarative, figurative) of the world picture and refers to the isolation of units (objects) that constitute that picture, the second one - evaluative - contains information about the subjective attitude of the individual towards the isolated objects, the third - logical and operational (procedural) - regards the analysis of relations between objects, that is the organization and structure of the world picture.

\section{World representation in the adolescence stage}

Research conducted under Gurycka's instruction $(1994,1996)$ provided valuable data about the content of the material world representation in high school youth. The subjective world of the youth is dominated by two opposing values: on one hand, young people search for pleasure connected with possessing material comforts and playful contacts with peers, however, on the other hand - they focus on existential issues such as the aim and sense of life, moral values, religion. The world of the youth concentrates on the central "I" category which has positive features, but is also a source of anxiety, hesitations and reflections. The world picture is filled with positive feelings revealed towards people, objects and values being the structural units of the subjective world, while negative emotions of fear and anxiety appear in relation to the future. The world picture of the youth reflects its reflectivity and humanism, as well as independence (Tarnowski, 1996, 1998). It contains elements that are crucial owing to the present course of the individual's developmental process and life events ahead of it.

The analysis of the world representation in the early adolescence stage was performed by Bulla (1997) with the use of Child's Living Space method. The world of younger youth is mostly filled with close people and peers towards whom positive feelings dominate, as well as with institutions, the natural environment and particular material values. The younger youth relatively rarely express their interests and existential values in the world structure. 
Comprehensive research carried out by Świda-Zięba (2000) contributes to the knowledge about the values of the present Polish youth. The representation of oneself and the world that functions in the minds of adolescents was also a subject of the author's analyses. One of the elements of this picture's structure is the creation of future plans that are connected with future time perspective. A young man starts to gain knowledge about his/her own feelings, needs, attitudes and possibilities. Gaining knowledge about oneself as a result of experiences with the outer world enriches and establishes the picture of one's own person and the picture of the world. Knowledge of oneself, one's needs, values, ideals and skills plays an important role in shaping life plans and the actions of the individual. Future plans creation makes it possible to obtain greater autonomy, self-determination, management of one's own life and development. In the adolescence period, life plans are not worked out yet. In this period, the individual creates a vision of a perfect world in which he/she also finds a place for himself/herself. $\mathrm{He} / \mathrm{She}$ extends life plans, sometimes very remote ones, but often little realistic as they still do not sufficiently allow for opportunities in the form of outer objective conditions and their own predispositions.

\section{World representation in the disabled and chronically ill youth}

Time perspective as an element of the world representation appears in the youth with a mild level of intellectual disability. This youth also make plans for the future, think and dream about becoming self-dependent, which they reveal by expressing their own expectations and desires. But limitations in the intellectual sphere, lack of the ability of abstract thinking do not however enable to perceive significant connections between one's own action and its effects. These restrictions do not allow to predict the course of events happening independently of the subject. It hinders the possibility of influencing the course of events and one's own fate, and taking intended and intentional actions. As a consequence, the youth with a mild level of intellectual disability have difficulties in defining states which do not exist yet, or in creating realistic plans for the future. They also often cannot evaluate their conduct skills appropriately. They assess various social situations from the perspective of one's own I, not being able to look at the given situations from the perspective of others (Kowalik, 1989).

In comparison with the healthy youth, young people with motor dysfunctions construct less diverse maps of the world, which is the result of objective limitations in interpersonal relations, caused by locomotion limitations (Wilk, 2000, as in Pilecka, 2002). Physical limitations cause lower sense of influence on oneself, on other people and on the course of events, and also lesser material scope of the world representation. However, this less intense physical activity is conducive to inner reflection and 
development of the value system, in which God, being its keystone and central point, plays a particular role.

God and spiritual values are also dominant elements in the world representation in the youth with asthma (Jabłońska, 2001, as in Pilecka 2002). The ill youth's representation of the world, despite numerous similarities in the scope of emotional content and color to the picture in the healthy youth, is characterized by peculiar dichotomy of two categories: God and his attributes and the church. God is connected with the accepted system of values, especially with love and the good, whereas the church is associated with participation in collective forms of religious life. In spite of the material differentiation, both categories are very important for the youth with asthma and are two sources of support - spiritual and social. The healthy youth probably derive social support from other sources, hence the church plays a less important role in their subjective world.

The world representation is somewhat differently constructed by the youth with insulin-dependent diabetes (Nitecka, 2001, as in Pilecka, 2002). The material scope of the world representations created by this group of the youth is smaller, but social relations and material comforts take a special place in it. Values and other dimensions of the spiritual world do not decide about the representation content in a significant way. The color of the constructed vision of the world is definitely positive. Elements of the real world dominate in the world representation of the ill youth, which shows a huge need of action and the conviction of one's own efficacy and personal influence on the course of events.

\section{World representation in the youth with conduct disorders}

Children and the youth with adaptive difficulties, and boys in the first place, create a negative and threatening representation of the social environment (Pilecka, 2002).

The research on the world representation in the youth with conduct disorders was carried out by Kossewska (2000). The youth aged 15-17 under the custody of the Emergency Fostering took part in the research due to the specificity of their personal experiences and particular course of socialization process and considerable level of moral corruption. The studied youth committed crimes against property, health and life - fights, robberies, thefts, and therefore were under institutional custody. The control group was high school youth paired with the youth from the experimental group as regards the similarity of independent variables (age and sex). Cognitive representation of the world in the minds of the youth with conduct disorders was determined on the basis of A. Gurycka's (1994) method - "The Map of My World".

The Emergency Fostering is a kind of emergency educational care center where children deprived of constant and appropriate parental care are sent. Emergency centers provide a child, who is partially or entirely deprived of parental care and in a crisis 
situation, with an emergency, 24-hour care, education adjusted to the age and developmental possibilities, care and education until return to the family, or placement in a foster family, socialization or family facility. These centers may connect intervention, socialization and therapeutic activities towards the child and his/her family.

The Emergency Fostering arranges the first stage of care for children and the youth aged 7-18. Children who run away from home, or from other educational care centers, who wander around streets, do not have their own house, who are minor victims of domestic violence, stay at the shelter. Not infrequently they are the youth who infringed the law and were sent to the shelter on the basis of the regulations of the Act on Juvenile Delinquency Proceedings. Juvenile delinquents are placed there for the time of a pending trial. A considerable percentage of the children come from families dominated by alcoholism, violence, poverty, unemployment and all kinds of addictions.

Emergency Fostering also organize rehabilitative, therapeutic and compensatory activities and help the children with fulfilling their schooling obligation.

The quoted studies of the cognitive world representation in the minds of the youth with conduct disorders revealed characteristic features of its inner picture of the world. Concentration on oneself is a crucial feature that is shown by defining a central object from which links in the direction of other objects split radially. Most often, one's own "I" is the central object, and in that case the world representation is of egocentric character (Neff, 1996). This central type of the world picture proves an intensified egocentrism in comparison with the control group. Egocentrism is a natural, though developmentally earlier stage of personality structure shaping process and also a symptom of the intensified self-affirmation need which could not be met by satisfactory interpersonal relations with significant people. According to Urszula and Mariusz Filla's (1996) research findings, the "l" category is more frequent in the youth than in adults, more often in boys than in girls. Egocentrism takes multiple forms (Zaborowski, 2002), at least two of which - basic and cognitive egocentrism - may be found in the studied youth, the result of which may be cognitive decentralition process inhibition consisting in the integration of one's own perspective with the perspectives of other people.

The central place of one's own person in the world representation is a characteristic feature in the adolescence period and influences narrowing the area of interests and the idealization of one's own individuality. Neff's studies (1996) showed that the centric type is however a form of some impoverished world vision dominated by objects connected with the closest family circle, providing - in families properly fulfilling their functions - a sense of security. People with this type of world representation do not show particular interests in social life, so they do not have ambitions to play a dominant role in it, they do not start reflection on philosophical issues but do not experience inner conflicts either. The presence of objects with the pronoun "my" symbolizes the spread of the "I" boundaries on other significant elements that become important components of the inner psychical world. It may result from a pathological relation with the object in 
childhood (Gasiul, 1992). More often, in comparison with the control group, placement of one's own person on the Map of the World and attributing more importance to it, as well as lack of emotional color towards oneself - neither positive nor negative emotions, nor reflection - show serious inner conflicts being the basis for antisocial conduct forms that is an immediate reason for placing the child in an Emergency Fostering.

Lack of reflection towards oneself may reveal difficulties in the process of selfeducation consisting in learning how to undertake actions and meet obligations. This process starts as early as in childhood and reaches its maximum after the adolescence period and, as the results show, is more intense in the youth from the control group. Self-creation competence, that is the wisdom of experience boosting resistance to stress and helping to cope with failures and life's adversities, is an effect of self-education (Przetacznik-Gierowska, 1993).

The elements of the world in the youth with conduct disorders are less often connected with positive links. The limited network of emotional bonds in the world of the youth, on the basis of broad studies conducted in England, is regarded as one of the factors of social environment that determines antisocial conduct (Radochoński, Perenc, 2000).

The world representation in the youth under the custody of the Emergency Fostering is characterized by lesser maturity, which was particularly shown in the number of isolated objects, not related to the other elements of the subjective world. Incoherence in the subjective picture of the world seems to follow from the conflict character of the relations between the individual and his/her closest social environment. Polarized families present contradictory attitudes towards important issues and events and normative patterns, which causes lack of sense of security and hinders the formation of a coherent picture of the world in children (Satir, 2002).

However, in the youth with conduct disorders negative and conflict relations between the "Self" and family members appeared, even if negative emotions towards them were not shown. So, concentration on oneself may be a defense reaction serving the reduction of negative emotions connected with traumatic experiences from interpersonal relations with the members of one's own family, it may also reduce the ability to anticipate future goals and plans aimed at the future - however, if they appear, they are very specific and do not have many details (job, family).

The youth under the custody of the Emergency Fostering feels the possibility of exerting influence on particular elements of one's own individual world in a much weaker way than the control group, which may result from a weaker expectation of one's own efficacy (Bandura, 1977, Domańska-Najder, 1984, as in Poznaniak 1998). Actions taken by the wards of the institution are more often situation-conditioned in its subjective interpretation than dependent on one's own competencies, the evaluation of which may also be lowered. 
The experience of lesser personal influence on the elements of one's own world suggests that the "Self" does not fulfil controlling or central function in decision-making mechanisms. Losing control over the world (the life, action) leads to acquired helplessness, which may be treated as a fixed defense mechanism reducing the risk of failure, and also reducing negative emotions, or as a manifestation of a low sense of one's own efficacy or coherence that play a vital role in the process of coping with life adversities (Antonovski, 1995).

In comparison with the control group, the world representation in the youth with conduct disorders is more saturated with elements of the real world and material objects. Institutions fulfilling care and educational functions also appear more often. From Gurycka's (1998) studies it follows that school is a frequent element of the youth's picture of the world, however, owing to the fact that the autonomy of the youth staying at the center is obviously limited, institutions that define the frames of the living space dominate in their world representation. However, school does not have much meaning for the youth from both groups and negative emotions are shown towards it. School remains in conflict with other objects as it limits interests' development, hence, is not conducive to harmonize with the world of the youth. Although the youth under the custody of the Emergency Fostering have limited possibilities of influencing their own individual real world, still, they do not show so many negative emotions towards formal institutions as the control group. The observed difference between the studied groups can be analyzed on two levels: the individual - allowing for the individual's needs and the institutional one - following from the diversity of institutions and their functions. The youth from the control group experience many negative emotions towards school, which in relation with the educational system reform became an institution that only fulfils the curriculum, and social life and pursuing one's own interests moved outside school boundaries. On the other hand though, formal education is a crucial element of the plan for the future, so anxiety connected with the fear of failure and time pressure appears. For the youth from the Emergency Fostering, institutions which are objects of the real world, fulfil complex functions: rehabilitative, training and educational. They create a present environment in which the youth develop and may meet their personal needs under controlled conditions. Personal traits of counselors and teachers in relation to institutions may have a significant meaning to the wards, among which emphatic sensitivity and the ability to understand the ward's situation are particularly important as for this group they substitute a parent, they are not only specialists implementing the curriculum (Morgan, 1984, Kliś, Kossewska, 2000). 


\section{World representation in the youth with hearing impairment}

Hearing impairment is the factor influencing individual experience and development. However, as it influences the identity development, it might also impact the world representation understood as a system of knowledge comprising an individual's information and beliefs developing as the individual gains experience.

In the study of deaf adolescents done by Kossewska (2012) subjects aged 15-17 were tested individually with the applied method called "Map of My World" by Gurycka (1994). It was showed that there is a great similarity of the world representation developmental pathway between the deaf and the hearing in the scope of the presence of future temporal orientation The Deaf adolescents present significantly fewer time categories on their world representation than the hearing ones do. They are usually related to present real objects, such as school, peer and family relationships, dating. The world of hearing adolescents includes more future time perspective which is related to vocational as well as social and personal goals.

Polish Deaf adolescents attend segregated school and usually live in a dormitory outside their family. Social life and realisation of interests have moved out of the family. For deaf and low-hearing youths, institutions of the real world perform complex functions: socialisation, education and upbringing. Institutions create a controlled environment where young people may develop and satisfy their needs. They give them a chance to realise the need of influence which is very important in the development of a mature, responsible personality. Present time perspective may limit the range of deaf adolescents'judgements, decisions and actions. Only few deaf youths pointed out the prolong education and profession as important values within the future context, while according to Zimbardo and Boyd (1999), a more future-based time perspective could help students study and progress to higher education. Deaf and hearing adolescents develop in relatively less secure environments, thus according to Evolutionary Life Theory, it may be followed by present oriented behavioural strategies, which reflect an orientation towards immediate outcomes and little concern for future consequences.

This finding may result from the fact that $90 \%$ of deaf children are born to hearing parents, and these children may not have received any usable language input during critical language acquisition periods of brain development. Lacking language input during a child's earliest years and the underdevelopment of a formal language system can result in an adult without fluency or competence in any language, including sign language (Sacks, 1989). Hearing family usually creates the low-stimulating developmental environment. Possession of a language system is necessary to facilitate abstract thinking, mature personality development and future goal orientation. Without such a system, some deaf persons may lack the ability to think abstractly or to generalize concepts. The development of future time orientation might be also limited by the low 
level of verbal communication skills, as to a result of the issue, an average deaf adult reads English at a fourth grade level (Haskins, 2000).

\section{Conclusions}

1. The world representation presenting the inner picture of the real world that emerged in the minds of the youth in connection with their socializing experiences fulfils a vital regulative function.

2. The representation of the world possessed by the youth with conductive disorders in comparison with the youth from the control group has specific features: the centric type of the world picture - containing the general "I" category; more saturation with real and material objects; lesser expressed sense of influence; fewer positive links between objects; lesser maturity.

3. The peculiarity of the representation of the world in the youth with conduct disorders results from diverse socializing experiences involved in interpersonal relations in the family.

4. The analysis of the material world representation may present an important element of personality structure development process and the basis for creating individual therapy program and the rehabilitative process of the youth with conduct disorders, a ward of the Emergency Fostering involved in infringing the law.

5. Building narration around the cognitive world representation revealed by the youth with conduct disorders may be a crucial element of family therapy, conducted from the perspective of the theory of systems as well as from the cognitive-behavioral one, and also of prevention and preventive measures and supporting the areas within which development is not disturbed.

6. The Deaf and hard-hearing Polish adolescents present significantly fewer time categories on their world representation than the hearing ones do. They are usually related to present real objects as school, peer and family relationships, dating. The world of hearing adolescents includes more future time perspective which is related to vocational as well as social and personal goals.

\section{References}

Antonovsky, A. (1995). Rozwikłanie tajemnicy zdrowia. Jak radzić sobie ze stresem i nie zachorować, Warszawa: Fundacja IPN.

Bartmiński, J. (1990). Językowy obraz świata. Lublin: UMCS,.

Bulla, B. (1997). Stosunek badanych dzieci do własnej osoby i świata. In M. John-Borys (Ed.), Pomoc dzieciom zagrożonym patologia środowiska rodzinnego i lokalnego. Katowice: Wydawnictwo Uniwersytetu Śląskiego, pp. 123-134. 
Fila, U., Fila, M. (1996). Charakterystyka obiektów Map Mojego Świata młodzieży i dorosłych. [in:] A. Gurycka (Ed.), Typologia i funkcje obrazu świata w umyśle człowieka. Poznań: Wydawnictwo Fundacji Humaniora, pp. 39-52.

Gasiul, H. (1992). Oblicza „ja” w świetle wybranych koncepcji psychologicznych. Pojęcie rozwój patologia. Bydgoszcz: Wydawnictwo WSP.

Gurycka, A. (1994). Reprezentacja świata w umysłach młodzieży-geneza. Warszawa: Pracownia PTP.

Gurycka, A. (1996). Typologia i funkcje obrazu świata w umyśle człowieka. Poznań: Wydawnictwo Fundacji Humaniora.

Gurycka, A. (1998) Charakterystyka wybranych źródeł autorytetów na podstawie badań nad światopoglądem. In A. Gurycka, T. Neff \& A. Tarnowski (Eds.), Jak ludzie spostrzegaja swój świat. Warszawa: Wydawnictwo Akademickie „Żak”, pp. 91-100.

Kielar-Turska, M. (1998). Umysłowa reprezentacja świata dziewięciolatka na przykładzie analizy znaczenia słowa mądrość. In M. Smoczyńska (Ed.), Studia z psychologii rozwojowej i psycholingwistyki. Kraków: Universitas, pp. 179-188.

Kielar-Turska, M. (2005). Rozwój reprezentacji poznawczej na przykładzie potocznej wiedzy o polityce. In Ledzińska M., Rudkowska G. \& Wrona, L. (Eds.). Psychologia współczesna: oczekiwania i rzeczywistość. Kraków: Wydawnictwo Naukowe AP, pp. 203-216.

Kliś, M. \& Kossevska, J. (2000). Studies on Empathy. Kraków: Wydawnictwo Naukowe AP.

Kofta, M. \& Doliński, D. (2000). Poznawcze podejście do osobowości. In J. STRELAU (Ed.), Psychologia. Podręcznik akademicki.t 2. Gdańsk: Gdańskie Wydawnictwo Psychologiczne, pp. 561-600.

Kossevska, J. (2006). Representation of the World in Youth with Conduct Disorders. In Kliś, M., Kossewska, J. \& W. Czajkowski. Studies on Communications and Doping with Stress. Kraków: WN AP.

Kossewska, J. (2012). Temporal Orientation as the Attribute of World Representation in Deaf Adolescents. Poster presentation $1^{\text {st }}$ Conference on Time Perspective, Coimbra, Portugal, 5.-8. 9. 2012.

Markus, H. (1983). Self-knowledge: An Expanded View. Journal of Personality, vol. 51, pp. 543-565.

Morgan, S. (1984). An Illustrative Case of High-empathy Teachers. Humanistic Education and Development, vol. 1, pp. 70-83.

Neff, T. (1996). Mapa Mojego Świata w świetle projekcyjnej interpretacji rysunku In A. Gurycka (Ed.), Typologia i funkcje obrazu świata w umyśle człowieka. Poznań: Wydawnictwo Fundacji Humaniora, pp. 90-139.

Pilecka, W. (2002). Przewlekła choroba somatyczna w życiu i rozwoju dziecka. Problemy psychologiczne. Kraków Wydawnictwo UJ.

Poznaniak, W. (1998). Teorie uczenia się społecznego jako model normalnego i zaburzonego funkcjonowania jednostki oraz grupy. In H. Sęk (Ed.), Społeczna psychologia kliniczna. Warszawa: PWN, pp. 70-98.

Przetacznik-Gierovska, M. (1993). Rozwój człowieka a samowychowanie. Wykład na II Krajowej Konferencji Psychologów Rozwojowych. Przegorzały, 6-9.

Radochoński, M. \& Perenc, L. (2000). Rozwój osobowości antyspołecznej w ontogenezie In F. Kozaczuk \& M. Radochoński (Eds.), Aktualne problemy pedagogiki resocjalizacyjnej i patologii społecznej. Rzeszów: Wydawnictwo WSP, pp. 45-69.

Sacks, O. (1989). Seeing Voices: A Journey into the World of the Deaf. Berkeley, CA: University of California Press.

Santrock, J. W. (2007). A Topical Approach to Life-Span Development. New York, NY: McGraw-Hill.

Satir, V. (2002) Rodzina. Tu powstaje człowiek. Gdańsk: Gdańskie Wydawnictwo Psychologiczne.

Świda-Zięba, H. (2000). Obraz świata i bycia w świecie: z badań młodzieży licealnej, Warszawa: UW.

Tarnowski, A. (1996). Typologia światopoglądu na podstawie ilościowej analizy Map Mojego Świata. In A. Gurycka (ed.), Typologia i funkcje obrazu świata w umyśle człowieka. Poznań: Wydawnictwo Fundacji Humaniora, pp. 53-89. 
Tarnowski, A. (1998). Humaniści, społecznicy, pragmatycy. In A. Gurycka, T. Neff \& A. Tarnowski Jak ludzie spostrzegaja swój świat. Warszawa: Wydawnictwo Akademickie „Żak”, pp. 17-40.

Zaborowski, Z. (2002). Człowiek, jego świat i życie. Próba integracji. Warszawa: Wydawnictwo Akademickie „Żak".

Zimbardo P. \& Boyd J. (1999). Putting Time in Perspective: A Valid, Reliable Individual-Difference Metric. The Journal of Personality and Social Psychology, vol. 77, pp. 1271-88.

\section{Contact:}

Joanna Kossewska, Ph.D.

Pedagogical University

Department of Psychology

30-084 Krakow, Poland

Podchorazych St. 2

e-mail: Joanna.Kossewska@ap.krakow.pl

The Faculty of Law, Palacký University, Olomouc cordially invites you to the second year of the international scientific conference "Mediation 2013 - The way to Cooperation and Conciliation", which will be held from $27^{\text {th }}$ to $28^{\text {th }}$ September 2013 at the Faculty's premises. The conference will be organised in three parts. Initial presentations given by the main speakers will be followed by lectures in individual sections: Mediation in legal and social context, Mediation as a method, Application fields of mediation and the Profession of a mediator. The third part of the Conference will consist of workshops with practical demonstrations of mediation techniques and activities of professionals and organisations engaged in mediation. For further information including electronic registration form see: http://www.mediaceolomouc.eu/ 